\title{
Food between Health and Society
}

\author{
Pietro Columba* \\ Department of Agricultural and Forest Sciences, University of Palermo, Italy \\ Submission: November 11 2016; Published: January 30, 2017 \\ *Corresponding author: Pietro Columba, Department of Agricultural and Forest Sciences, University of Palermo, Italy, \\ Email: pietro.columba@unipa.it
}

\section{Introduction}

Food culture has undertaken a process of renewal due to severe food safety problems occurred in the late $20^{\text {th }}$ century: the so called mad cow disease (BSE, Bovine Spongiform Encephalopathy) or the swine flu and bird flu. So long, safety needs were the beginning of a new consciousness about food and diet influence on human health. The demand for quality food is moving toward qualitative food features. This is a great challenge and a new opportunity for agriculture: to supply valuable goods and new services, to a wide range of consumers, searching for local, ecological, ethical, healthy requisites, from food and country. A new sensibility is also growing about urban life quality; overcrowded cities hardly supply the needed services and suffer for the loosening of the contact with the environment and the countryside. Food is nowadays the way territory is supplied inside the town: a food that is evocative of nature and history, healthy and correlated with the share of social values.

\section{Quality Food}

Market competition allocates goods in quantity but fails in allocating their quality. At the same time, environmental goods, the so called non-price goods, are not regulated by market; this results in waste of ecological resources due to disregarding the cost of their reproduction, because: in the long run we are all dead (J. M. Keynes in “A Tract on Monetary Reform”, cap. 3, 1923). Driven by rising economy and population, the food market as always been a growing market but in the last years, a decrease in food consumption has been registered in developed countries as a result of economic recession and demographic stability. In this context agriculture has had to pursue better economic results no longer through higher efficiency and returns to scale but through an enhanced quality, able to meet a higher willingness to pay of the consumers for typical and healthy food Cantarelli [1]. For example, in Italy from 2011 to 2014 the value of PDO or PGI certified food is raised by $5 \%$, in the meanwhile not certified food is fallen by $3 \%$ (Figure 1).

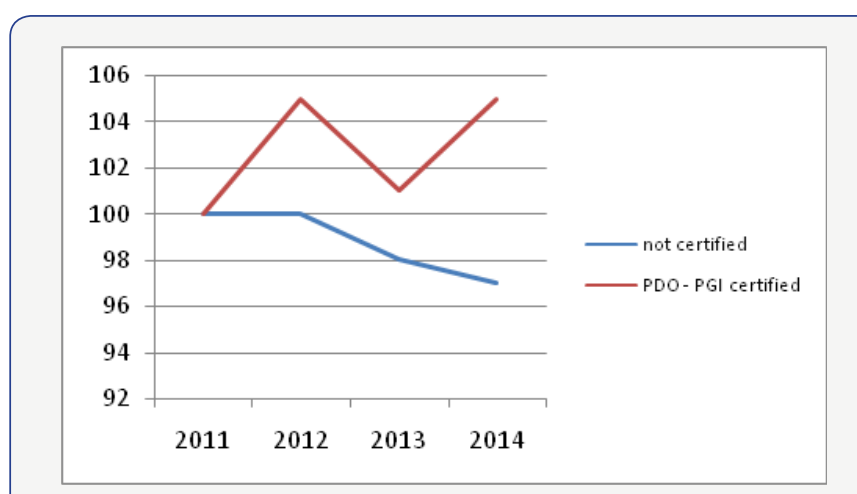

Figure 1: Comparison among PDO-PGI certified and not certified food value Index $2011=100$.

Source: processing of ISMEA data, Qualivita report.

Moreover, the demand for quality has been boosted by the need to ensure food safety, but is now related with healthy diets too; according with a new consciousness of the role food plays in causing metabolic diseases because of overeating or when poor in quality. The safe and healthy diet is therefore a demanded need of consumers and also a public good because of the need to prevent public health costs and losses in human capital. The market demand for quality food is therefore driven by the search for: health, environment, landscape, culture, ethic values but also agriculture and gastronomy specificities. Through the use and the sharing of goods with such characteristics, the user wants to tell the others his own view of life; food is the mean to express oneself. So that, if in the market economy, man is defined for his economic function of consumer, the post-modern vision defines him as a consum-actor, meaning that he pursue the aim to play an active role, conscious and oriented to relations, in his purchase of goods and services (touristic, relational, healthy, etc...) Viganò et al. [2].

Nowadays, quality is intended to be a way to conceive the social relations; is a shared convention and can be obtained 
by sharing the territory by the resident population, and results from the dialogue among the producers and among the producers and the consumers Distaso [3]. Once quality is defined through many different aspects: environment, health, culture, relations; it clearly appears that territory is an attribute of the quality of goods. The new competition on market is a competition among territories; goods, whose characteristics are related with the territory, are, then, typical, differentiated, and hardly reproducible outside the area of origin. A qualitative and competitive territory is shared by people living in it; people that feel to belong to the territory and that cooperate in the pursue of common objectives Distaso [3]. We can say: quality is a dimension of the community life.

\section{The Relation between Man and Land}

Industrialized agriculture is based on highly mechanized and labour saving techniques; therefore, crops and livestock require much less work and families no longer attend to the farms. In the developing process of the economy, agriculture weight decreases while the share of industrial activities and service industry rise; so, the productive centre of gravity has moved from countryside towards the town. Since the sixties of the twentieth century a massive movement from country (the so called "rural exodus "analysed by agricultural economists) has caused depopulation and environmental degradation. At the same time, to receive the rising population, cities have been growing under the influence of the economic needs and the possibilities offered by transport and building technologies.

According to a very critical interpretation, modern town has developed following the rules of capitalism, where every element is intended for a total control of space and of the man living in it Atkinson [4].

A recent study [ ] has analysed Sarcelles, one among the Villes Nouvelles around Paris, where: men leave early in the morning to go to work and go back home late in the evening. Habitants complain of boredom and depression... is a town where it is impossible to meet each other Columba GM [5]. Our overgrown towns have lost the contact with the territory and citizens are isolated from each other.

\section{Town and Countryside}

To overcome the restraints of urban living, citizens demand for rurality; agriculture supplies restoration and rural tourism but also a food representative of local specificities: territory becomes a part of the goods themselves Scarso e Squadrilli [6], while quality food carries rural territory inside the town. Urban agriculture and gardens, farmer's markets and purchasing groups, are the effect of a mutual return of the green into the town: places of direct exchange between producer and user of zero kilometres products. Finally, new organized distribution forms [2] were born, based on local goods and deploying a multifunction approach: local food supply, education, debate, catering.

A basic condition for healthy and fair urban living depends on the food environment I [3]; it can be described through: the location of retail outlets in a community; the range and types of foods available to consumers; the information provided to consumers about foods; and organizational structures which affect food access and availability (such as retail networks). Public health problems resulting from poor diet are tightly linked to the food environment found in a community. The eating behaviours- and the likelihood of being obese - are influenced by what's readily available in the community. Retail food outlets that sell affordable, high quality, nutritious foods can encourage a healthy diet, reducing an individual's risk for chronic diseases, including obesity and diabetes. Higher RFEI (Retail Food Environment Index) has been shown to be correlated with increased obesity in the USA and around the world.

$R F E I=\quad$ fast food restaurants + convenience stores supermarkets + small grocery stores + farmers markets

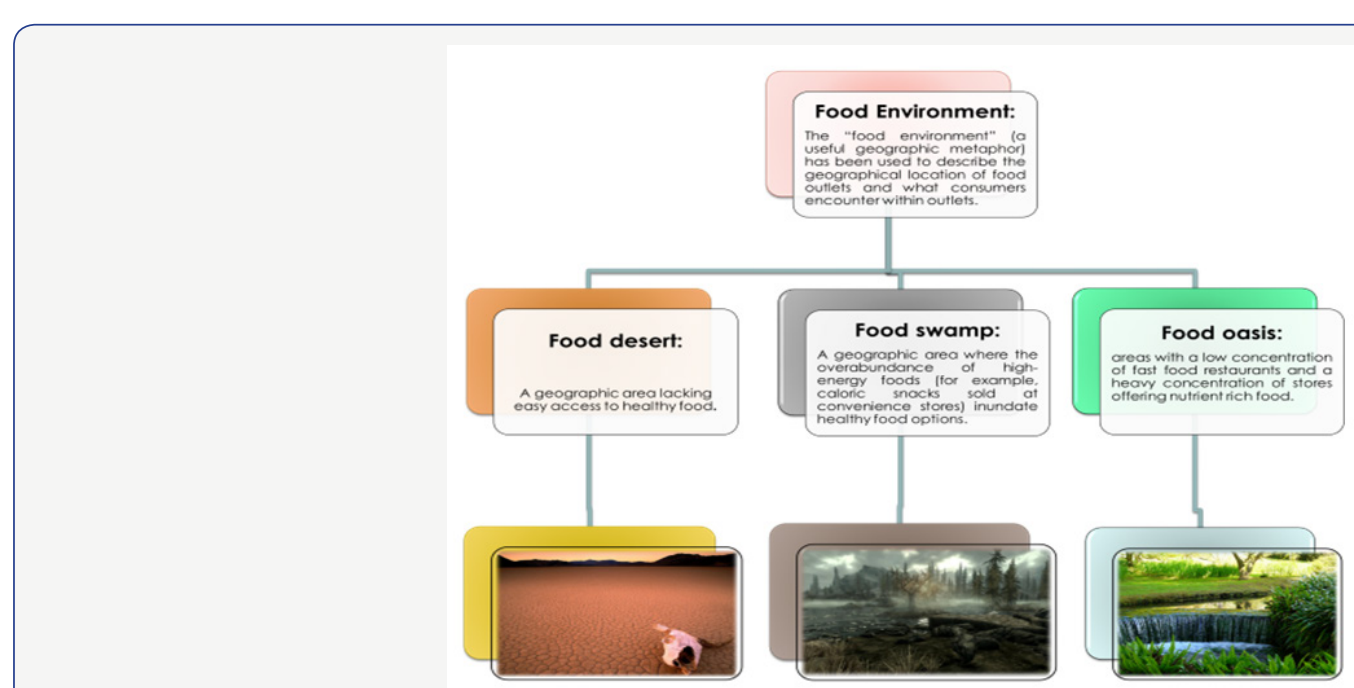

Figure 2: Food Environments. 
A high-quality food environment is a necessary condition for the adoption of healthy eating behaviors. Healthful food strategies should focus on changing food environments to improve overall community health. (Figure 2). An assessment of the food landscape, by mapping the retail environment, land use patterns and street network, as well as analysing local policies and codes relevant to food access, can help stakeholders make the right decision for their community. Observational measures of the quality of retail food environments, as characterized by availability, accessibility and pricing, provide a useful method for comparing food environments between neighbourhoods. Food Oasis is a metaphor focused on developing innovative, self-sustaining ways to empower residents of food deserts to get better access to healthy foods. Whether we define it as a desert or a swamp, everyone needs easy access to healthy, affordable food. A preliminary study was carried on in the third District (III Circoscrizione) of the city of Palermo; an area of 2,034.7 hectares, which population counts 74,144 units. Data were collected on field and uploaded using GIS software. In the study area were found 306 food shops and restaurants [ ]. The study revealed a process of urban desertification due to the disappearing of small food shops that affects the whole city area of Palermo Columba et al. [7].

\section{Conclusion}

The food topic relevance in towns is more and more growing and may become critical in next year's. Some local governments are now working to identify innovative urban policies on food (food plans), promoting studies able to identify problems related to proper food management and defining coherent action plans in urban areas. The main objectives, the city governments pursue, are: improving health, knowledge and consciousness on food topic amid the citizens; accessibility of quality food consumption; sustainability (availability, food waste, recycling, environmental and energetic impacts, etc.).Similarly, the Italian Wine Cities Association has recently promoted the development of the regulatory plans of wine cities, a planning approach based on the rural heritage surrounding the cities.

The quality of the territory and the quality of food are tightly linked and are basic elements of the functional integration between urban and rural areas by offering both environmental attractiveness - environmental services - and touristic usability. Searching for an improved life quality (instead of searching for profit only) means that planning the city is planning the surrounding territory as well. Rural areas can be seen as the connective tissue among the parts composing the r-urban (rural and urban) landscape as a whole. This joint planning may counteract the impacts of the spread urbanisation and contribute to avoid the urban sprawl on the rural land; may give birth to qualified places for exchanging, sharing and having leisure; may, finally, provide the new technologic functions of a green town (i.e. renewable energy production, sustainable waste management, etc.).
Relational Integrated Tourism could, in this context, join together several components of local specific characters: new extended city, landscape archaeology, rural villages, quality food and agriculture, sustainable tourism, relations Naselli [8]. A new arrangement of the territorial components should start by the comprehension of a renewed role that citizens may take in governance choices for the rural landscape, according with profitable relationships they can build (or-rebuild) between man and environment: the inseparable context, landscape - heritage food, can and indeed must, do not generate new customers, but new citizens [5, 9-15].

\section{References}

1. Cantarelli F (2005) I tempi alimentari del Mediterraneo: cultura ed economia nella storia alimentare dell'uomo, Franco Angeli, Milano, pp. 560

2. Viganò E, Antonelli G, Bischi GI, Tramontana F (2015) Consumo e consumatori di prodotti alimentari nella società postmoderna. Economia Agro-Alimentare, Anno XVII, n. 1, Francoangeli, Milano, Italy.

3. Distaso M (a cura di, 2007) Il territorio fonte di vantaggio competitivo, in L'agro-alimentare tra economia della qualità ed economia dei servizi, ESI, Napoli, p. 19-35.

4. Atkinson M (2009) "Parkour, Anarcho-Environmentalism, and Poiesis". Journal of Sport \& Social Issues 33(2): 169

5. Columba GM (2015) Sport metropolitani ovvero, sul bisogno dello spazio pubblico. Il Parkour: interazioni tra l'arte dello spostamento e l'habitat urbano, Tesi di laurea.

6. Scarso SG, Squadrilli L (2015) Marketing del gusto. La guida completa per promuovere i prodotti tipici e i servizi di ristorazione e organizzare eventi enogastronomici. LSWR, Milano.

7. Columba P, Oliveri Y, CuzzupéG (2014) Food deserts, food swamps, food oases: A matter of food accessibility. Poster, Convegno Agricoltura, cibo e salute, Palermo 19-20/09/2014.

8. Columba P, Naselli F, Trapani F, Mingrino F (2016) MutAzione: un approccio innovativo al turismo per lo sviluppo delle aree interne. XIX Conferenza Nazionale SIU. Catania, 16-18 giugno.

9. Columba P, Naselli F, Trapani F (2015) Un approccio mediterraneo il "ritorno alla campagna" e il ruolo del turismo per le aree interne, in: AA.VV, Atti della XVIII Conferenza Nazionale SIU. Italia '45-'45. Radici, Condizioni, Prospettive, Venezia, 11-13 giugno 2015, Planum Publisher, Roma Milano, pp: 514-520.

10. Columba P, Naselli F, Trapani F (2015) Agricoltura, alimentazione e paesaggio nei territori produttivi. Intrecci disciplinari tra piano e programmi di sviluppo nei casi della Sicilia centrale. In: Moccia FD, Sepe M (a cura di) IX Giornata Studio INU, Infrastrutture blu e verdi, reti virtuali, culturali e sociali. Urbanistica Informazioni, special issue, 263, settembre-ottobre. INU edizioni, ISSN n. 0392-5005.

11. Columba P, Oliveri Y, Cuzzupé G (2014) Indagine sul Food Environment nel Comune di Palermo. Poster, Convegno Agricoltura, cibo e salute, Palermo 19-20/09/2014

12. Cummins S (2007) Neighbourhood food environment and diet-Time for improved conceptual models? Preventive Medicine 44(3): 196-197.

13. Di Iacovo F, Brunori G, Innocenti S (2013) Le strategie urbane: il piano del cibo. Agriregionieuropa anno $9 \mathrm{n}^{\circ} 32$, Mar p: 9.

14. Moore L, Diez Roux A (2006) Associations of neighbourhood characteristics with the location and type of food stores. Am J Public Health 96(2): 325-331. 
15. Morland K, Wing S, Diez Roux A, Poole C (2002a) Neighbourhood characteristics associated with the location of food stores and food service places. Am J Prev Med 22(1): 23-29.

This work is licensed under Creative Commons Attribution 4.0 License

DOI: $10.19080 / N F S I J .2017 .02 .555583$

\section{Your next submission with Juniper Publishers} will reach you the below assets

- Quality Editorial service

- Swift Peer Review

- Reprints availability

- E-prints Service

- Manuscript Podcast for convenient understanding

- Global attainment for your research

- Manuscript accessibility in different formats

( Pdf, E-pub, Full Text, Audio)

- Unceasing customer service

Track the below URL for one-step submission https://juniperpublishers.com/online-submission.php 